\title{
Titanian garnet in nepheline syenite from the Kaleybar area, East Azerbaijan Province, NW Iran
}

\author{
Robab Hajialioghli, Mohssen Moazzen \\ Ralf Milke \\ Department of Geology, University of Tabriz, Tabriz \\ Institut für Geologische Wissenschaften, \\ Freie Universität, Berlin
}

\begin{abstract}
The Kaleybar nepheline syenite intrusion forms the largest silica undersaturated alkaline exposure in northwestern Iran. It consists of various rock types ranging from nepheline syenite to nepheline diorite that were emplaced during Eocene-Oligocene times, corresponding to the Alpine orogeny. The essential rock-forming minerals in nepheline syenite are plagioclase, K-feldspar, nepheline and amphibole. Clinopyroxene is the dominant phase in nepheline diorites. Titanian garnet occurs as an uncommon accessory phase forming reddish to deep brown individual grains.

Chemically it is intermediate between Ti-andradite (67 to 78 mole \%) and grossular (21 to 33 mole $\%$ ) with $\mathrm{TiO}_{2}$ contents ranging from 1.5 to $5.0 \mathrm{wt} \%$. Stoichiometry and R-mode factor analysis on garnet chemistry show that the dominant exchange vectors are Si-Ti and Al-Fe substitutions in the tetrahedral and octahedral crystal sites, respectively. A magmatic origin of the investigated Ti-garnet is suggested on the basis of mineralogical criteria and chemical properties.
\end{abstract}

Keywords: alkaline undersaturated rocks, Ti-garnet mineral chemistry, statistical R-mode factor analysis, stoichiometry, Kaleybar, NW Iran

\section{Introduction}

Alkaline igneous rocks are volumetrically insignificant in the earth's crust $(<1 \%$ of all rock types), but they include wide geochemical and mineralogical variety. One of the rather uncommon accessory phases of alkaline rocks is titanian garnet (e.g. Ti-bearing garnet in nepheline syenite: Gomes 1969; in syenite: Ramasamy 1986; Turbeville 1993; Lang et al. 1995; Jiang et al. 2003; in ankaramite: Segalstad 1979; in ijolite-melteigite: Larsen 1942, Mitchell and Platt

Addresses: R. Hajialioghli, M. Moazzen: 51664 Tabriz, Iran, e-mail: hajialioghli@tabrizu.ac.ir R. Milke: Malteserstr. 74-100, 12249 Berlin, Germany

Received: May 10, 2011; accepted: October 20, 2011 
1979, and in phonolite: Azambre and Girod 1966; Varet 1969; Dingwell and Brearley 1985), which apart from its igneous occurrence is also found in skarns, hydrothermal assemblages and infrequently low to high-grade metamorphic rocks (Deer et al. 1982; Dingwell and Brearley 1985). In comparison with metamorphic garnets, distinguishing between skarn-associated garnet, hydrothermal garnet and magmatic garnet derived from highly differentiated magma is more controversial. Studies by Cioni et al. (1995), Russell et al. (1999), Naimo et al. (2003), Smith et al. (2004) and Fulignati et al. (2004) classify Ti-garnet in various rocks on the basis of textural features and major oxides criteria. Recently Scheibner et al. (2007) discriminated magmatic from hydrothermal titanian garnet by means of rare earth element fractionation on garnet chemistry.

Gwalani et al. (2000) considered crystallization of magmatic Ti-garnet in relation to anhydrous conditions and Ti-rich composition of alkaline undersaturated magmas.

The garnet formula of silicate garnets may be written $\{X\}_{3}\{Y\}_{2}\{Z\}_{3} \mathrm{O}_{12}$. The $\mathrm{X}$ cation site is eight coordinated, the $\mathrm{Y}$ cation site is six-coordinated and the $\mathrm{Z}$ cation site is four-coordinated (cf. review by Novak and Gibbs 1971). Melanite is a variety of titanian andradite that has $\mathrm{Ti}<1$ atom per formula unit (Deer et al. 1982). Deer et al. (1997) used the term melanite for those varieties of titanium andradite which have $\mathrm{Fe}^{3+}>\mathrm{Ti}$ in octahedral coordination.

The incorporation of $\mathrm{Ti}$ is in principle possible both on octahedral and tetrahedral sites of the garnet structure. Many investigations have been carried out to determine the site occupancy of $\mathrm{Ti}, \mathrm{Al}$ and Fe in Ti-garnet (e. g. Kunitz 1936; Tarte 1960a, b; Howie and Woolley 1968; Hartman 1969; Huggins et al. 1977a, b; Dingwell and Brearley 1985; Russell et al. 1999; Gwalani et al. 2000; Chakhmouradian and McCammon 2005). In the present study the crystal chemistry of Ti-garnet is investigated to reveal the character of cation distribution in the crystal structure of the Kaleybar garnets using multivariate statistical Rmode factor analysis and stoichiometry; the garnet's potential magmatic origin is discussed based on mineralogical and chemical properties.

This is the first study on the mineralogy of the alkaline undersaturated rocks from the Kaleybar nepheline syenite intrusion.

\section{Geologic setting}

The Kaleybar area is located between latitude $46^{\circ} 53^{\prime}$ and $47^{\circ} 05^{\prime} \mathrm{E}$ and longitude $38^{\circ} 45^{\prime}$ and $38^{\circ} 52^{\prime} \mathrm{N}$ in the province of East Azerbaijan, NW Iran. In terms of the structural subdivision of Iran the study area is included in the West Alborz-Azerbaijan Zone (Nabavi 1976; Fig. 1a). The Kaleybar intrusion, with an area of $70 \mathrm{~km}^{2}$, forms the largest alkaline body in northwestern Iran (Fig. 1a). Its emplacement into the Cretaceous sediments and volcanic rocks has formed a thermally metamorphosed aureole up to $1 \mathrm{~km}$ in width (Fig. 1b; Hajialioghli 2002). Occasionally the calcareous rocks are found as crustal xenoliths, $10 \mathrm{~cm}$ in 
diameter, in the alkaline rocks. The timing of intrusion of the Kaleybar pluton is not precisely known. An Eocene-Oligocene age of intrusion can be assigned in view of stratigraphic relationships as well as relative and isotopic dating of the analogous plutons from nearby areas in Azerbaijan (35-40 Ma: K-Ar and Rb-Sr dating; Bagdasarian 1966; Gukasian 1963) and Armenia (37-40 Ma: K-Ar and RbSr dating; Bagdasarian 1966) (Fig. 1b). Petrologic and compositional similarities of

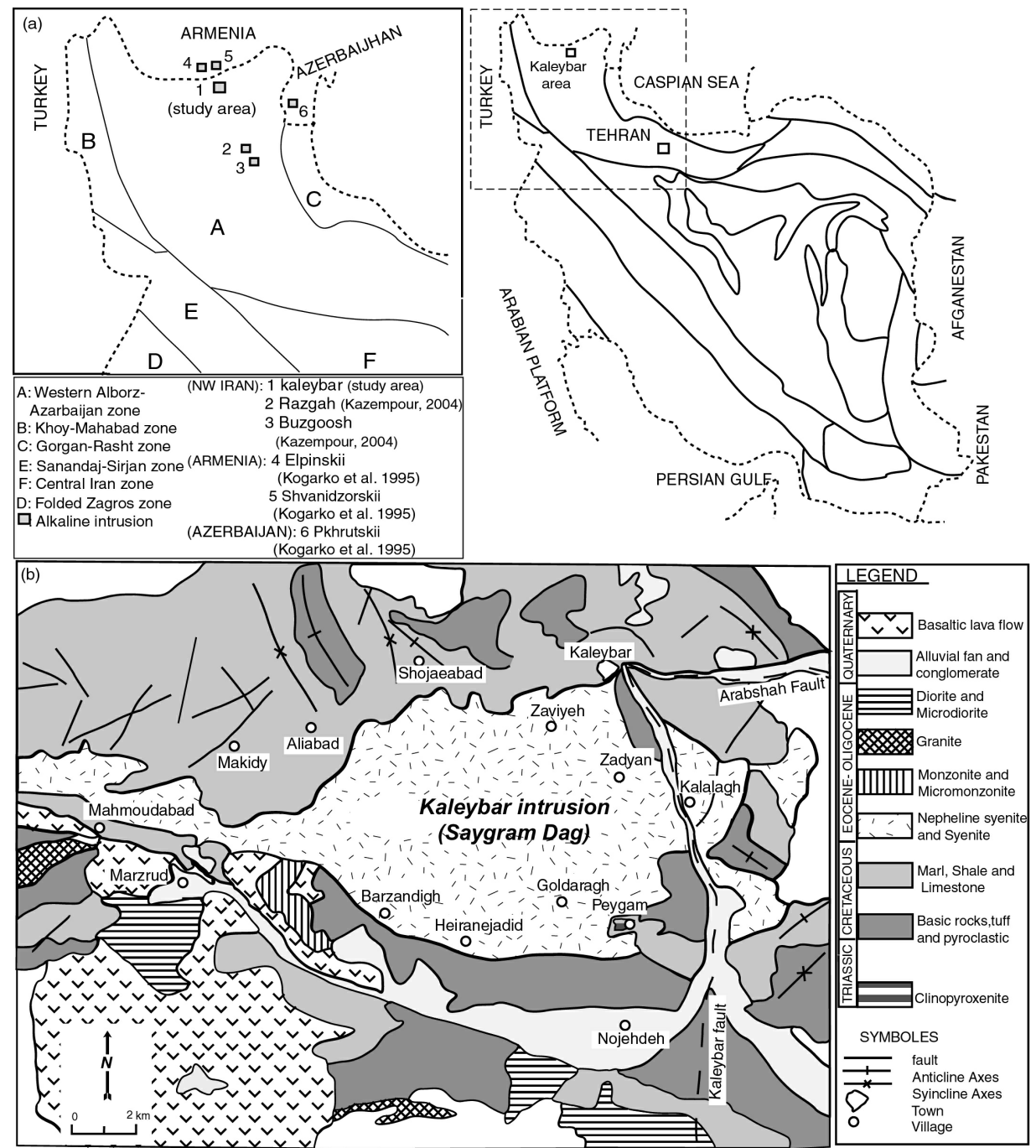

Fig. 1

a) Location of the study area within the structural subdivision map of Iran (Nabavi 1976). b) Geologic map of the Kaleybar area (adapted from Babakhani et al. 1980) 
rock types from all the alkaline undersaturated intrusions in NW Iran (i.e. Kaleybar, Bozgush and Razgah intrusions: Fig. 1b) most probably suggest their contemporaneous generation. Riou (1979) considered all these rocks in association with undersaturated compositions from Azerbaijan and Armenia, corresponding to the Caucasus Alpine orogeny.

Lithologically the Kaleybar intrusion is composed of a variety of rock types, including nepheline syenite, nepheline monzodiorite, nepheline diorite and sporadically granite and clinopyroxenite. Nepheline syenite has a very different leucocratic color index (10-30 vol\% mafic minerals) from the mesotype one for nepheline diorite (40-60 vol\% mafic minerals), depending on the modal amounts of amphibole and clinopyroxene. Rare clinopyroxenite occurs near the village of Peygam. It is likely in association with the Kaleybar alkaline undersaturated magmas (Fig. 1b). Compositionally two types of dyke are seen in the area. An intensely altered lamprophyre dyke, in which biotite phenocrysts occur in a finegrained matrix, obscuring the primary mineralogy, is located near the village of Makidy (Fig. 1b); a nepheline syenite dyke with pegmatitic texture intruded into the nepheline syenite rock near the villages of Kalalag and Barzandig (Fig. 1b). Nepheline occurrences up to $5 \mathrm{~cm}$ in diameter are distinguishable in nepheline syenite dyke.

\section{Petrography}

The mineral abbreviations used here are after Kretz (1983), except Opa for opaque phase and Amp for amphibole.

1. Nepheline syenite: K-feldspar (30-35 vol\%), plagioclase (20-30 vol\%), nepheline (up to $25 \mathrm{vol} \%$ ) and amphibole (15-20 vol\%) are major constituents. Kfeldspar can reach up to $8 \mathrm{~mm}$ in diameter (Fig. 2a). Microcline with tartan twinning is seen in some samples. Nepheline is hydrated variously in these rocks. Secondary analcite/sodalite is formed as a rim around nepheline (Fig. 2b). Figure $2 \mathrm{c}$ shows an SEM image of analcite/sodalite and hydronepheline with intergrowth texture. Analcite/sodalite can be distinguished by isotropic extinction. Nepheline of $1 \mathrm{~mm}$ diameter occurs occasionally with interstitial texture between large feldspars. Titanite, biotite and $( \pm)$ clinopyroxene occur in minor amounts. Garnet, opaque phases, apatite and zircon are accessory minerals. Euhedral to subhedral garnet exhibits reddish to deep brown colors (Fig. 2a, b).

2. Nepheline diorite: The rocks are dominated by plagioclase (50-60 vol\%), clinopyroxene (20-25 vol\%), amphibole (10-15 vol\%) and nepheline (5-10 vol\%). Coarse-grained plagioclase, $2 \mathrm{~mm}$ in diameter, is full of clinopyroxene inclusions. The modal abundance of K-feldspar is fairly low and some samples are K-feldspar free. Nepheline is highly pseudomorphed to analcite/sodalite aggregates. 
Occasionally interstitial nepheline occurs between plagioclase lathes. Clinopyroxene is pale green in color and approaches up to $3 \mathrm{~mm}$ in diameter. Secondary amphibole of a deep green color is formed around clinopyroxene or has completely replaced it (Fig. 2e). Accessory minerals include apatite, titanite and opaque phases.

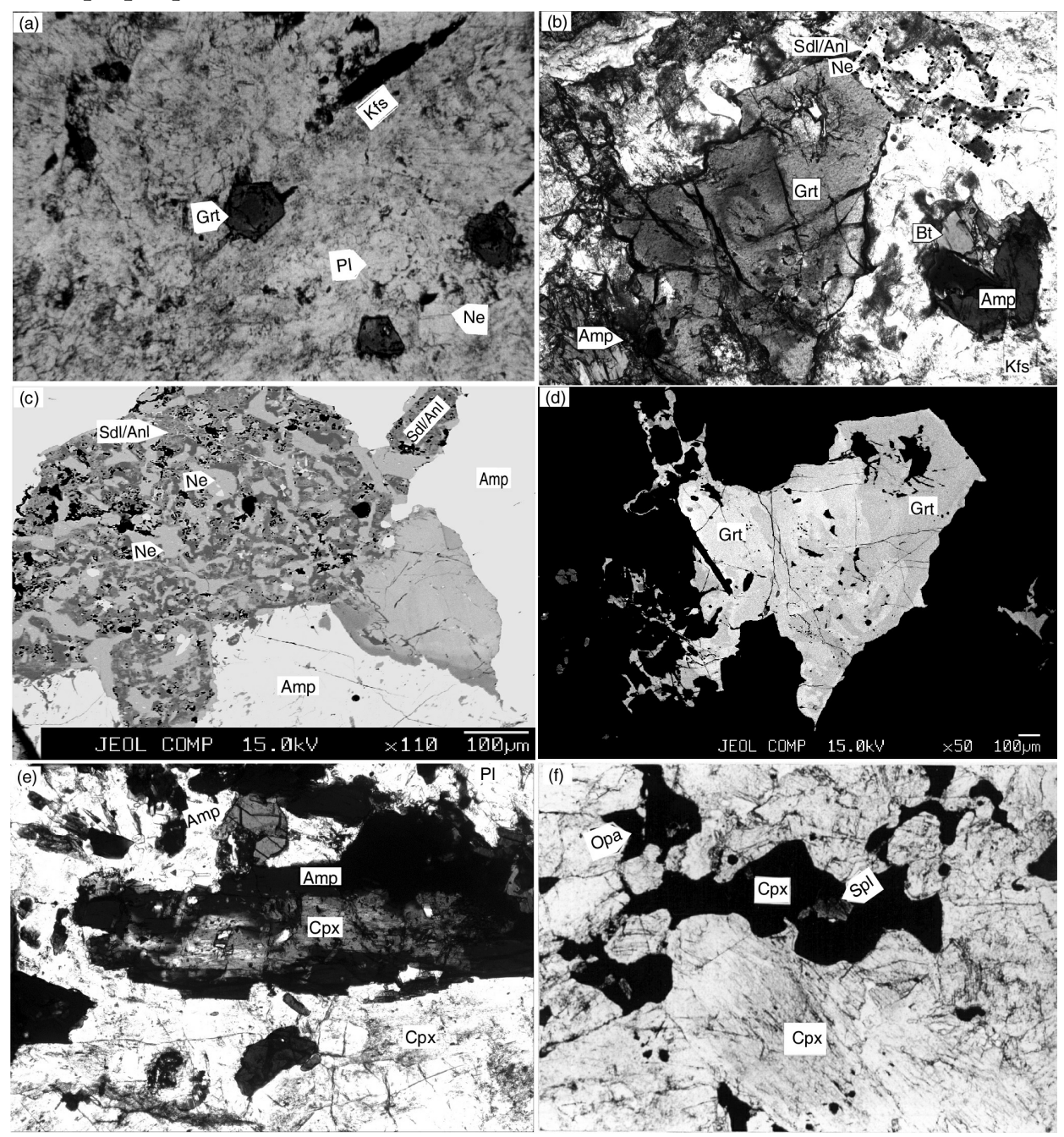

Fig. 2

a) Large K-feldspar and subhedral garnet in nepheline syenite. PPL, field of view $7 \mathrm{~mm}$. b) Subhedral individual garnet in nepheline syenite. PPl, field of view $2.5 \mathrm{~mm}$, (c) SEM image of secondary analcite/sodalite and hydronepheline. Secondary analcite/sodalite is also seen around nepheline. (d) SEM image of zoned garnet with variation in color. (e) Amphibole around clinopyroxene in nepheline diorite. PPL, field of view $1.25 \mathrm{~mm}$. (f) Spinel inclusion in opaque phase in clinopyroxenite. PPl, field of view $2 \mathrm{~m}$. Grt - garnet, $\mathrm{Pl}$ - plagioclase, $\mathrm{Ne}$ - nepheline, $\mathrm{Sdl}$ - sodalite, Anl - analcite, $\mathrm{Bt}$ - biotite, Amp - amphibolite, Kfs - K-feldspar, Cpx -clinopyroxene, Opa - opaque phase 
3. Clinopyroxenite: Clinopyroxenite is a medium to coarse-grained rock. The constituent minerals are clinopyroxene (up to $90 \mathrm{vol} \%$ ) and opaque minerals (10-25 vol\%) (Fig. 2f). Tiny deep green spinel (hercynite) is enclosed by an opaque phase (Fig. 2f). Secondary amphibole forms ragged areas or rim on clinopyroxene.

\section{Mineral chemistry}

Major element compositions of clinopyroxene, feldspars, amphibole, biotite and titanian garnet were determined at the Freie Universität Berlin by electronmicroprobe JXA- 8200 super probe at an accelerating voltage of $15 \mathrm{kv}, 20 \mathrm{nA}$ beam current. Standards used for calibration are jadeite $(\mathrm{Na}, \mathrm{Al})$, hornblende $(\mathrm{K}, \mathrm{Ti})$, plagioclase $(\mathrm{Ca})$, pyrope $(\mathrm{Mg}, \mathrm{Si})$, chromite $(\mathrm{Cr})$, almandine $(\mathrm{Fe})$, rhodonite $(\mathrm{Mn})$ and synthetic $\mathrm{ZnO}(\mathrm{Zn})$. All analyses were $\mathrm{ZAF}$ corrected. Representative mineral compositions are presented in Tables 1-2.

1. Feldspar: Both K-feldspar and plagioclase compositions are plotted on an AbAn-Or ternary diagram (Fig. 3a). K-feldspar composition is $\mathrm{Or}_{74.00-88.50} \mathrm{Ab}_{11}$ ${ }_{17} \mathrm{An}_{0.5-2.0}$. Plagioclase is weakly zoned with more albitic rims $\left(\mathrm{Ab}_{62-65} \mathrm{An}_{4-37}\right.$ $\left.\mathrm{Or}_{0.5-1.1}\right)$. Andesine is the main constituent.

2. Amphibole: The chemical composition of amphibole is represented in Table 1. Ferric iron content is estimated using the method of Droop (1987), assuming the sum of $\mathrm{Si}, \mathrm{Ti}, \mathrm{Al}, \mathrm{Cr}, \mathrm{Fe}, \mathrm{Mg}, \mathrm{Mn}=13.00$ per $23(\mathrm{O})$. The amphibole composition is characterized by relatively high titanium $\left(\mathrm{TiO}_{2}=1.7-3.0 \mathrm{wt} \%\right)$, potassium $\left(\mathrm{K}_{2} \mathrm{O}=2.3-2.4 \mathrm{wt} \%\right)$ and iron $(\mathrm{FeO}=17-23 \mathrm{wt} \%)$ contents. Secondary amphibole occurs as a rim around and as blebs in clinopyroxene. It has low $\mathrm{TiO}_{2}$ (ca. $1.18 \mathrm{wt} \%$ ) and high $\mathrm{MgO}$ (ca. $10.36 \mathrm{wt} \%$ ) contents. On the basis of the $\mathrm{Si}$ versus $\mathrm{Mg} /\left(\mathrm{Mg}+\mathrm{Fe}^{2+}\right)$ classification diagram $\left({ }^{\mathrm{A}} \mathrm{Na}+{ }^{\mathrm{A}} \mathrm{K}>0.5, \mathrm{Ti}>0.5, \mathrm{Fe}^{3+}<\mathrm{Al}^{\mathrm{IV}}\right.$; Hawthorne 1981), they are ferroan pargasite (Fig. 3b).

3. Clinopyroxene: The chemical composition of pyroxene is $\mathrm{Di}_{82.90-84.00^{-}}$ $\mathrm{Hd}_{7.50-10.40} \mathrm{Jd}_{1.30-1.80} \mathrm{Ae}_{5.10-7.00}$. Aluminum content ranges between 3.7 and 4.5 $\mathrm{wt} \%$, and sodium concentration is up to $1.10(\mathrm{wt} \%)$. The titanium concentration lies between 0.50 and $0.54(\mathrm{wt} \%)$. The $\mathrm{Mg}$-number $(\mathrm{Mg} \# \mathrm{Mg} /(\mathrm{Mg}+\mathrm{Fe}))$ is high, ranging from 89 to 92 . The $\mathrm{Mg}-\mathrm{Na}-\left(\mathrm{Mn}+\mathrm{Fe}^{2+}\right.$ ) diagram (Fig. 3c) indicates diopsidic composition for the analyzed clinopyroxene. They are characterized by an enrichment of the wollastonite component $\left(\mathrm{Wo}_{52.00-52.30} \mathrm{En}_{35.30-35.50^{-}}\right.$ $\left.\mathrm{Fs}_{11.60-12.40}\right)$. On the $\mathrm{Ca}_{2} \mathrm{Si}_{2} \mathrm{O}_{6}-\mathrm{Mg}_{2} \mathrm{Si}_{2} \mathrm{O}_{6}-\mathrm{Fe}_{2} \mathrm{Si}_{2} \mathrm{O}_{6}$ diagram they plot in the salite field (Fig. 3d).

4. Biotite: Titanium content in biotite is low $\left(\mathrm{TiO}_{2}=1.6-1.7 \mathrm{wt} . \%\right)$ but concentration of iron is high $(\mathrm{FeO}=22-23 \mathrm{wt} . \%)$. The composition is 


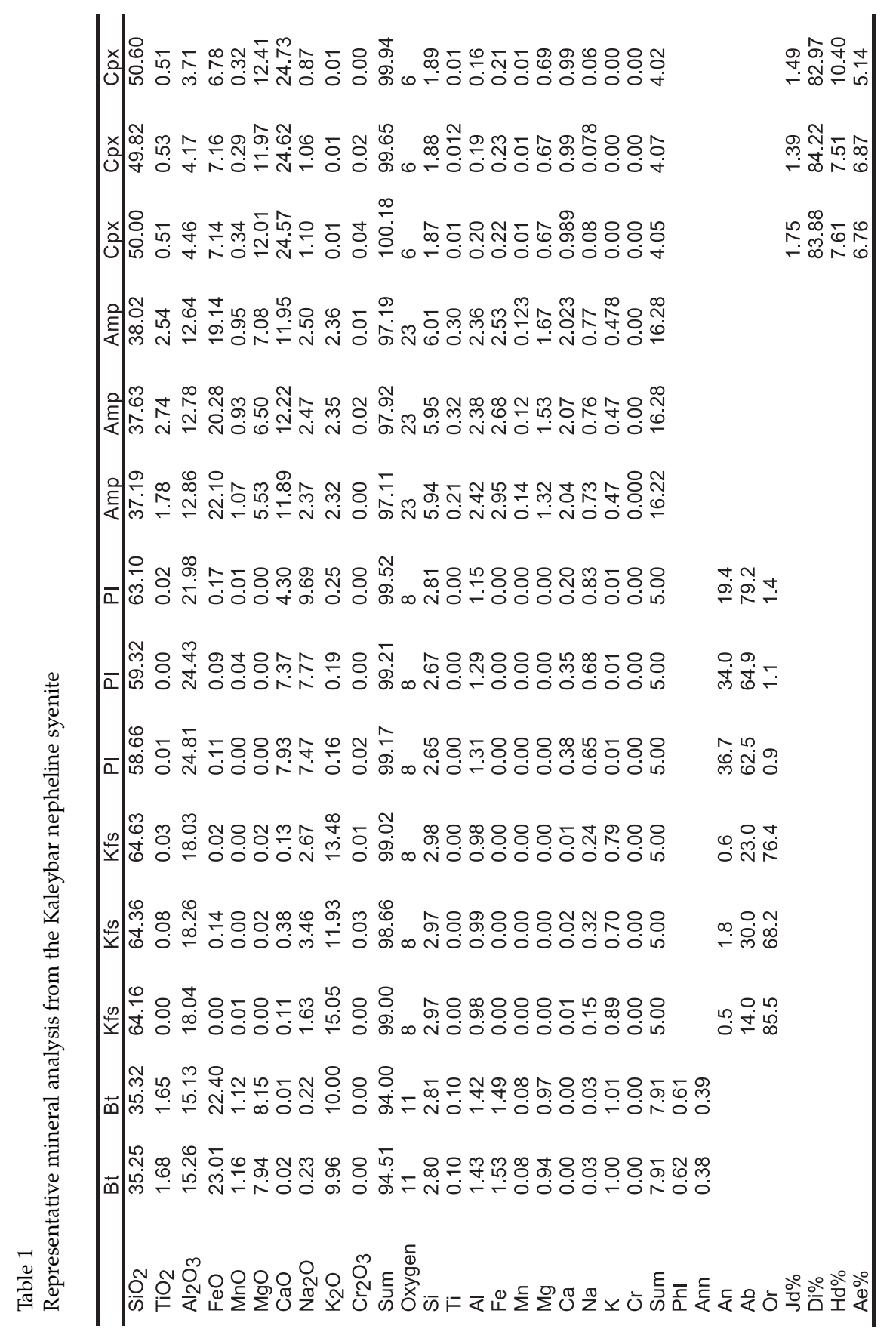


Table 2

Representative garnet analysis from the Kaleybar nepheline syenite

\begin{tabular}{llllllllll}
\hline & $\mathrm{Grt}$ & $\mathrm{Grt}$ & $\mathrm{Grt}$ & $\mathrm{Grt}$ & $\mathrm{Grt}$ & $\mathrm{Grt}$ & $\mathrm{Grt}$ & $\mathrm{Grt}$ & $\mathrm{Grt}$ \\
\hline $\mathrm{SiO}_{2}$ & 35.43 & 35.16 & 35.72 & 34.85 & 35.68 & 35.26 & 34.80 & 34.44 & 34.77 \\
$\mathrm{TiO}_{2}$ & 1.75 & 2.38 & 1.70 & 2.94 & 1.9 & 2.60 & 2.98 & 4.34 & 3.26 \\
$\mathrm{Al}_{2} \mathrm{O}_{3}$ & 5.72 & 5.13 & 5.42 & 4.94 & 5.43 & 5.01 & 4.81 & 5.16 & 6.95 \\
$\mathrm{FeO}$ & 22.92 & 23.03 & 23.70 & 22.87 & 23.00 & 23.04 & 23.55 & 21.97 & 18.58 \\
$\mathrm{MnO}$ & 1.24 & 1.24 & 1.10 & 1.19 & 1.19 & 1.20 & 1.25 & 1.50 & 0.97 \\
$\mathrm{MgO}$ & 0.14 & 0.14 & 0.17 & 0.23 & 0.16 & 0.18 & 0.18 & 0.26 & 0.14 \\
$\mathrm{CaO}$ & 34.66 & 34.18 & 34.05 & 33.72 & 34.19 & 33.86 & 33.55 & 33.5 & 35.3 \\
$\mathrm{Na} 2 \mathrm{O}$ & 0.03 & 0.07 & 0.05 & 0.06 & 0.05 & 0.05 & 0.08 & 0.08 & 0.01 \\
$\mathrm{~K} 2 \mathrm{O}$ & 0.00 & 0.00 & 0.00 & 0.00 & 0.00 & 0.00 & 0.00 & 0.00 & 0.00 \\
$\mathrm{Sum}$ & 101.80 & 101.30 & 101.90 & 100.80 & 101.60 & 101.20 & 101.20 & 101.25 & 99.98 \\
$\mathrm{Oxygen}$ & 12 & 12 & 12 & 12 & 12 & 12 & 12 & 12 & 12 \\
$\mathrm{Si}$ & 2.86 & 2.86 & 2.89 & 2.86 & 2.89 & 2.88 & 2.85 & 2.82 & 2.83 \\
$\mathrm{Ti}$ & 0.11 & 0.15 & 0.10 & 0.18 & 0.12 & 0.16 & 0.18 & 0.27 & 0.20 \\
$\mathrm{Al}$ & 0.54 & 0.49 & 0.52 & 0.48 & 0.52 & 0.48 & 0.46 & 0.50 & 0.66 \\
$\mathrm{Fe}$ & 1.40 & 1.41 & 1.45 & 1.41 & 1.40 & 1.42 & 1.46 & 1.34 & 1.14 \\
$\mathrm{Mn}$ & 0.08 & 0.09 & 0.08 & 0.08 & 0.08 & 0.08 & 0.09 & 0.1 & 0.07 \\
$\mathrm{Mg}$ & 0.02 & 0.02 & 0.02 & 0.03 & 0.02 & 0.02 & 0.02 & 0.03 & 0.02 \\
$\mathrm{Ca}$ & 3.00 & 2.98 & 2.95 & 2.96 & 2.97 & 2.96 & 2.94 & 2.93 & 3.08 \\
$\mathrm{Na}$ & 0.00 & 0.00 & 0.00 & 0.00 & 0.00 & 0.00 & 0.00 & 0.00 & 0.00 \\
$\mathrm{~K}$ & 0.00 & 0.00 & 0.00 & 0.00 & 0.00 & 0.00 & 0.00 & 0.00 & 0.00 \\
$\mathrm{Sum}$ & 8 & 8 & 8 & 8 & 8 & 8 & 8 & 8 & 8 \\
$\mathrm{And}$ & 1 & 1 & 1 & 1 & 1 & 1 & 1 & 1 & 1 \\
$\mathrm{Grs}(\%)$ & 26.6 & 24 & 25.1 & 23.1 & 25.4 & 23.4 & 22.1 & 22.8 & 32.7 \\
$\mathrm{Adr}(\%)$ & 73.3 & 76 & 74.9 & 76.9 & 74.5 & 76.6 & 77.8 & 77.2 & 67.3 \\
$\mathrm{Uva}(\%)$ & 0.1 & 0 & 0 & 0 & 0.1 & 0 & 0.1 & 0 & 0 \\
$\mathrm{H} 4 \mathrm{Si}-1$ & 0 & 0 & 0 & 0 & 0 & 0 & 0 & 0 & 0 \\
\hline & & & & & & & & &
\end{tabular}

$\mathrm{Ann}_{0.62} \mathrm{Ph}_{10.38}$. Figure 3e indicates a homogeneous composition for biotite in the $\mathrm{Al}^{\mathrm{IV}}{ }_{\text {vs. }}^{0.6 e} /(\mathrm{Fe}+\mathrm{Mg})$ diagram.

5. Garnet: Garnet is intricately zoned. The $\mathrm{TiO}_{2}$ content is in the range of 1.5$5.0 \mathrm{wt} \%$.

Inhomogeneous composition of the Kaleybar Ti-garnet is seen as various colors in SEM image (Fig. 2d). Light parts of the garnet contain relatively higher concentrations of $\mathrm{TiO}_{2}$ in comparison with dark parts with relatively lower $\mathrm{TiO}_{2}$ concentration (Fig. 2d). A similar feature for Ti-garnet from nepheline syenite was reported by Gomes (1969). $\mathrm{Al}_{2} \mathrm{O}_{3}$ concentration in Kaleybar garnets ranges from 4.8 to 6.95 (wt \%). The $\mathrm{Mg}$ content is very low (up to $0.26 \mathrm{wt} \%$ ). It can be assumed to show crystallization at a temperature below $950{ }^{\circ} \mathrm{C}$ (Green 1977). There is little agreement in the literature regarding the role of $\mathrm{Ti}$ in the structure of Ti-garnet, stoichiometry formula and assigning $\mathrm{Ti}, \mathrm{Al}$ and $\mathrm{Fe}$ to crystal sites. We have 

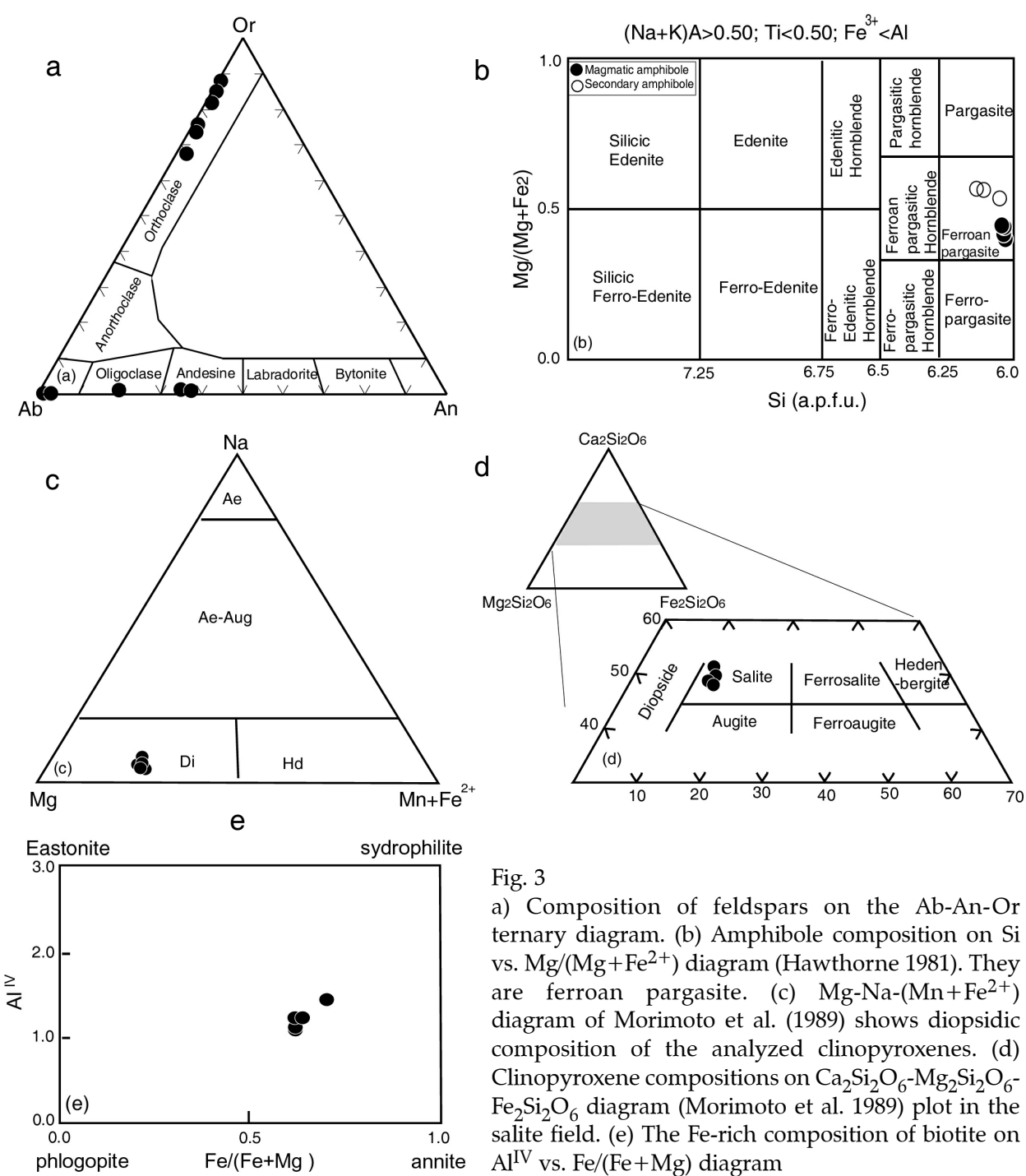

Fig. 3

a) Composition of feldspars on the Ab-An-Or ternary diagram. (b) Amphibole composition on Si vs. $\mathrm{Mg} /\left(\mathrm{Mg}+\mathrm{Fe}^{2+}\right)$ diagram (Hawthorne 1981). They are ferroan pargasite. (c) $\mathrm{Mg}-\mathrm{Na}-\left(\mathrm{Mn}+\mathrm{Fe}^{2+}\right)$ diagram of Morimoto et al. (1989) shows diopsidic composition of the analyzed clinopyroxenes. (d) Clinopyroxene compositions on $\mathrm{Ca}_{2} \mathrm{Si}_{2} \mathrm{O}_{6}-\mathrm{Mg}_{2} \mathrm{Si}_{2} \mathrm{O}_{6}$ $\mathrm{Fe}_{2} \mathrm{Si}_{2} \mathrm{O}_{6}$ diagram (Morimoto et al. 1989) plot in the salite field. (e) The Fe-rich composition of biotite on

concentrated on formula calculation and the significant cation substitutions in Tigarnets of the Kaleybar alkaline undersaturated rocks.

\section{Discussion and conclusions}

The mineral compositions of Ti-garnet from the Kaleybar nepheline syenite intrusion are illustrated on the $\mathrm{Ti}-\mathrm{Fe}^{3+}-\mathrm{Al}$ and $\mathrm{Ca}-\mathrm{Fe}^{3+}-\mathrm{Al}$ ternary diagrams (Fig. 4c). They are dominantly grandite binary solid solutions (95.6-97.3 mole \%), 

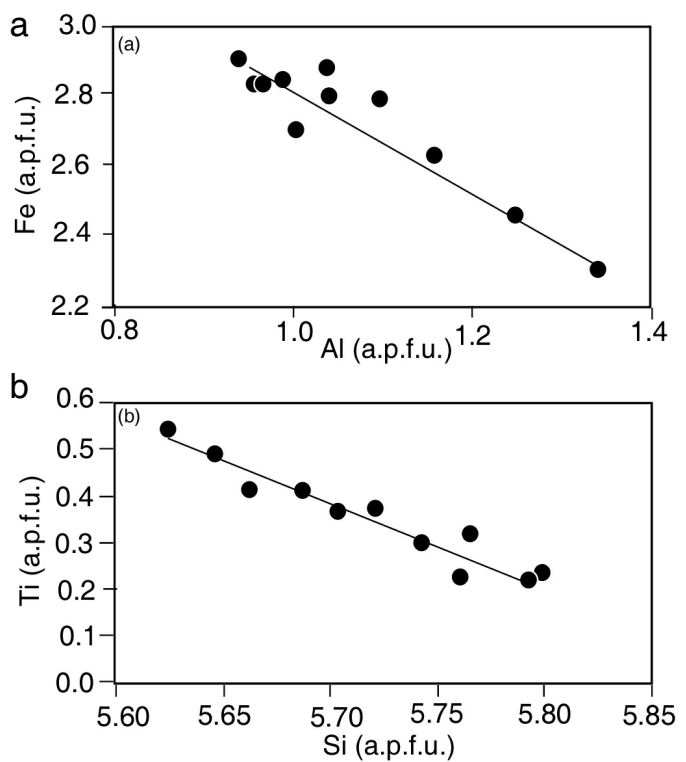

C

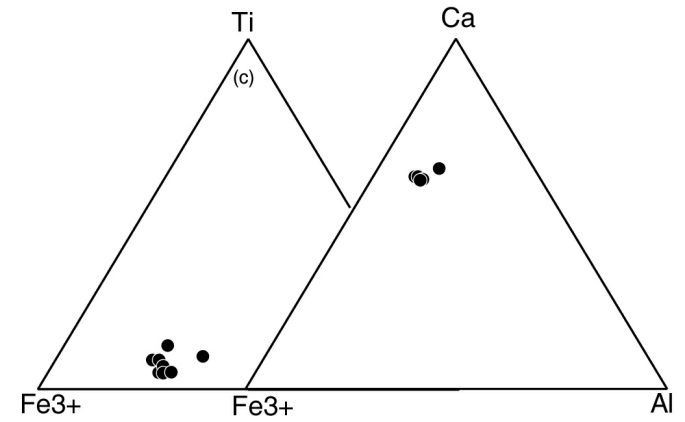

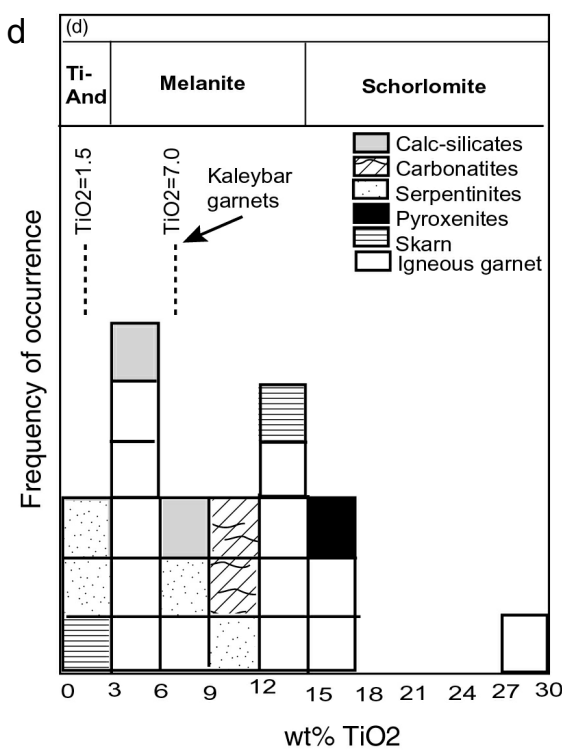

Fig. 4.

$\mathrm{a}, \mathrm{b})$ Negative covariations between $\mathrm{Si}$ $\mathrm{Ti}$ and $\mathrm{Al}-\mathrm{Fe}$ on garnet chemistry. (c) Garnet composition on the $\mathrm{Ti}_{-}-\mathrm{Fe}^{3+}-\mathrm{Al}$ and $\mathrm{Ca}-\mathrm{Fe}^{3+}-\mathrm{Al}$ ternary diagrams. (d) Garnet compositions range from Tiandradite to melanite, comparable to garnet compositions from various localities compile by Dingwell and Brearley (1985)

with a composition of $\mathrm{And}_{67-78} \mathrm{Grs}_{21-33}$. The minor components are pyrope and spessartine, up to 2.7-4.4 mole $\%$ (Table 2). $\mathrm{TiO}_{2}$ concentration ranges from $1.5 \mathrm{wt} \%$ to $7 \mathrm{wt} \%$ spanning the compositional range of Ti-andradite to melanite in Fig. $4 \mathrm{~d}$, which is comparable to garnet compositions from various localities, compiled by Dingwell and Brearley (1985) (Fig. 4d).

\section{Inferred substitutions}

The correlation coefficient of elements on the Kaleybar garnet is assumed to show the relationship between element pairs (Tables 3-4). The main negative correlations between $\mathrm{Si}-\mathrm{Ti}$ and $\mathrm{Al}-\mathrm{Fe}$, with correlation coefficients of -0.852 and -0.906 , respectively, undoubtedly represent exchange, whereas the minor correlations may or may not represent coupling in substitutions. Two of the strongest covariations between $\mathrm{Si}-\mathrm{Ti}$ and $\mathrm{Al}-\mathrm{Fe}$ are plotted in Fig. 4a and b. Since 
Table 3

Correlation coefficient matrix of exchange components for the Kaleybar titanian garnet

\begin{tabular}{|c|c|c|c|c|c|c|c|c|}
\hline & & $\mathrm{Si}$ & & $\mathrm{Al}$ & $\mathrm{Fe}$ & $\mathrm{Mn}$ & $\mathrm{Mg}$ & $\mathrm{Ca}$ \\
\hline $\mathrm{Si}$ & $\begin{array}{l}\text { Pearson Correlation } \\
\text { Sig. }\end{array}$ & 1 & & & & & & \\
\hline $\mathrm{Ti}$ & $\begin{array}{l}\text { Pearson Correlation } \\
\text { Sig }\end{array}$ & $\begin{array}{l}-0.852^{* *} \\
004\end{array}$ & 1 & & & & & \\
\hline $\mathrm{Al}$ & $\begin{array}{l}\text { Pearson Correlation } \\
\text { Sig }\end{array}$ & $\begin{array}{l}.004 \\
-3.20 \\
0.401\end{array}$ & $\begin{array}{l}.045 \\
909\end{array}$ & 1 & & & & \\
\hline $\mathrm{Fe}$ & $\begin{array}{l}\text { Pearson Correlation } \\
\text { Sig }\end{array}$ & $\begin{array}{l}.401 \\
.612 \\
.080\end{array}$ & $\begin{array}{l}.909 \\
-.433 \\
.244\end{array}$ & $\begin{array}{l}-.906^{* *} \\
.001\end{array}$ & 1 & & & \\
\hline $\mathrm{Mn}$ & $\begin{array}{l}\text { Pearson Correlation } \\
\text { Sig }\end{array}$ & $\begin{array}{l}-.354 \\
-.351\end{array}$ & .493 & $\begin{array}{l}.001 \\
-.634 \\
.067\end{array}$ & $\begin{array}{l}.406 \\
.278\end{array}$ & 1 & & \\
\hline $\mathrm{Mg}$ & $\begin{array}{l}\text { Pearson Correlation } \\
\text { Sig }\end{array}$ & $\begin{array}{l}.5 \\
-.463 \\
.210\end{array}$ & $\begin{array}{l}.669 \\
.051\end{array}$ & $\begin{array}{l}.001 \\
-.253 \\
.511\end{array}$ & $\begin{array}{l}.270 \\
.010 \\
.980\end{array}$ & $\begin{array}{l}.436 \\
.240\end{array}$ & 1 & \\
\hline $\mathrm{Ca}$ & $\begin{array}{l}\text { Pearson Correlation } \\
\text { Sig }\end{array}$ & $\begin{array}{l}.210 \\
.251 \\
.515\end{array}$ & $\begin{array}{l}.071 \\
.071 \\
.857\end{array}$ & $\begin{array}{l}.911 * * \\
.001\end{array}$ & $\begin{array}{l}-.837^{* *} \\
.005\end{array}$ & $\begin{array}{l}.240 \\
-.720^{*} \\
.029\end{array}$ & $\begin{array}{l}-.373 \\
.323\end{array}$ & 1 \\
\hline
\end{tabular}

Table 4

Coefficient of exchange components

\begin{tabular}{|c|c|c|c|c|c|}
\hline \multirow[t]{2}{*}{ Model } & \multirow{2}{*}{$\begin{array}{l}\begin{array}{l}\text { Unstandardized } \\
\text { coefficients }\end{array} \\
\text { B } \\
\end{array}$} & \multicolumn{2}{|l|}{$\begin{array}{l}\text { Standardized } \\
\text { coefficients }\end{array}$} & \multirow[t]{2}{*}{$\mathrm{t}$} & \multirow[t]{2}{*}{ Sig. } \\
\hline & & Std. error & Beta & & \\
\hline $\mathrm{Al}$ & -1.081 & .096 & -2.746 & -11.293 & .008 \\
\hline $\mathrm{Fe}$ & -1.216 & .106 & -4.76 & -11.487 & .007 \\
\hline $\mathrm{Mn}$ & -.953 & .158 & -.337 & -6.015 & .027 \\
\hline $\mathrm{Mg}$ & .858 & .269 & .154 & 3.190 & .086 \\
\hline $\mathrm{Ti}$ & -1.338 & .098 & -2.877 & -13.628 & .005 \\
\hline \multicolumn{6}{|c|}{ Dependent variable: $\mathrm{Si}$} \\
\hline \multirow[t]{2}{*}{ Model } & $\begin{array}{l}\text { Unstandardized } \\
\text { coefficients }\end{array}$ & $\begin{array}{l}\text { Standardized } \\
\text { coefficients }\end{array}$ & & $t$ & Sig. \\
\hline & $\mathrm{B}$ & Std. error & Beta & & \\
\hline $\mathrm{Al}$ & -.889 & .021 & -.577 & -41.853 & .001 \\
\hline $\mathrm{Mn}$ & -.764 & .167 & -.069 & -4.581 & .044 \\
\hline $\mathrm{Mg}$ & .716 & .194 & .033 & 3.696 & .066 \\
\hline $\mathrm{Ti}$ & -1 & .025 & -.603 & -43.840 & .001 \\
\hline $\mathrm{Si}$ & -1.338 & .071 & -.207 & -11.487 & .007 \\
\hline Depend & t variable: $\mathrm{Fe}$ & & & & \\
\hline
\end{tabular}

the correlation coefficient matrix cannot distinguish between these potential couplings or possible induced correlations between these elements, R-mode factor analyses of the garnet chemistry were performed as well (Table 5). Coupled 
Table 5

Rotated component matrix

\begin{tabular}{lll}
\hline & \multicolumn{2}{c}{ Component } \\
\hline & Factor 1 & Factor 2 \\
$\mathrm{Si}$ & 0.306 & -.902 \\
$\mathrm{Ti}$ & -.026 & .967 \\
$\mathrm{Al}$ & -.970 & .044 \\
$\mathrm{Fe}$ & .907 & -.399 \\
$\mathrm{Mg}$ & .318 & .742 \\
$\mathrm{Mn}$ & .707 & .556 \\
Eigenvalue & 3.41 & 2.78 \\
\%Variance & 48.67 & 39.66 \\
Cum. Var. & 48.67 & 88.34 \\
\hline
\end{tabular}

substitutions should show up as large factor loading in the results of the analysis (Table 5). Factor 1 has high loadings for $\mathrm{Al}(-0.971)$ and $\mathrm{Fe}(0.922)$, which accounts for $48.67 \%$ of the total variance. There are minor loadings for Si (0.342), Ti (-0.067) and Mg (0.288). Clearly, the principle exchange represented by this factor is $\mathrm{Al}$ for $\mathrm{Fe}$. Factor 2 has high loadings for $\mathrm{Si}$ $(-0.889)$ and $\mathrm{Ti}(0.965)$ and a minor loading for $\mathrm{Al}(0.005)$ and $\mathrm{Fe}(-0.362)$. This factor accounts for $39.67 \%$ of the total variance. Together factors 1 and 2 account for $87.34 \%$ of the variance in the data set, leaving less than $13 \%$ to be taken up by other components. Major factor loadings for others are insignificant as their eigenvalues are $<1$. The evident substitutions that may be inferred from these results are $\mathrm{Si}-\mathrm{Ti}$ and $\mathrm{Al}-\mathrm{Fe}$ cation exchanges. A similar process to determine Ti incorporation in the garnet structure on the basis of inter-element correlations was applied by Dingwell and Brearley (1985), Russell et al. (1999) and Gwalani et al. (2000).

\section{Stoichiometry and site assignments of cations in Ti-garnets}

The structural role of iron and titanium in Ti-rich garnet is complex because the tetrahedral site is usually deficient in silicon. There is no general agreement on the site assignment of cations in the structural formula of titanian garnet and its effect on various chemical substitutions. A great number of investigations have tried to determine the correct distribution of cations, particularly $\mathrm{Al}, \mathrm{Fe}$ and $\mathrm{Ti}$, among the crystallography sites. Hartman (1969), Huggins et al. (1977a) and McCammon (2005) suggested a tetrahedral site preference as $\mathrm{Al}^{\mathrm{IV}}>\mathrm{Fe}^{3+}>\mathrm{Ti}$. Si-Ti substitution in garnet was suggested by Kunitz (1936) and Tarte (1960a, b). Locock et al. (1995) and Peterson et al. (1995) considered the deficient in Si to be occupied by $\mathrm{Fe}^{3+}$ and substantial $\mathrm{Fe}^{2+}$. Howie and Woolley (1968), Huggins et al. (1977b), Basso et al. (1981), Onuki et al. (1981), Dingwell and Brearley (1985), Koenig (1886), Hoffmann (1902), Sawaki (1988), Russell et al. (1999) and Gwalani et al. (2000) assigned Ti to a tetrahedral site and stated that the Si-Ti exchange in natural Ti-garnets is the predominant substitute in garnet structure. Katerinopoulou et al. (2009) reported that the tetrahedrally-coordinated position is occupied by $\mathrm{Si}, \mathrm{Ti}^{4+}, \mathrm{Fe}^{3+}$ and $\mathrm{Al}^{3+}$. The remaining of $\mathrm{Fe}^{3+}, \mathrm{Al}^{3+}$ and $\mathrm{Ti}^{4+}$ are located in the sixfold coordinated site. 
In order to determine significant substitutions in the structural formula of the Kaleybar Ti-garnet, we preformed the stoichiometry and diadochies inferred from factor analysis on garnet chemistry from electron microprobe data. The estimated formula based on the method of Russell et al. (1999), assuming 8 cations and 12 oxygens, is given in Table 2. Iron was recalculated to $\mathrm{Fe}^{2+}$ and $\mathrm{Fe}^{3+}$ cations based on charge and cation balance consideration. According to Amthauer and Rossman (1998), "hydrogarnet" substitution $\left(\mathrm{SiO}_{4}\right)^{4-} \leftrightarrow\left(\mathrm{O}_{4} \mathrm{H}_{4}\right)^{4-}$ is important for andradite. In addition, $(\mathrm{OH})$ - anions can be incorporated in other positions in the garnet structure. Considering the lack of deficiency in anionic charges (Russell et al. 1999), hydroxial species (i.e. H4) is assumed to be absent in the calculated Ti-garnet formula (Table 2). Mineral vectors with a Thompson additive component (Thompson 1982) equal to 1.0 (And=1; Table 2), point to consistency of the calculated formula for the Ti-garnets from the Kaleybar alkaline undersaturated rocks.

The estimated mineral composition of Ti-garnets indicates that all $\mathrm{Si}$ was assigned to the tetrahedral site $(Z)$. The dominance of the $\mathrm{Si}-\mathrm{Ti}$ exchange in the analyzed garnets implies that Ti fills the rest of tetrahedral site. Remaining Ti was allocated to the octahedral site $(Y)$ since all the Ti cannot be accommodated in the tetrahedral site of these garnets by substitution for Si (Table 2). The dominant exchange involving $\mathrm{Ti}$ in the garnet is consistent with binary Si-Ti exchange (Table 5, Factor 2). In addition, the absence of significant factor loading in the Si-Ti exchange factor (Table 5), rules out the significant coupling of $\mathrm{Al}$ or $\mathrm{Fe}$ in this exchange. All Fe and $\mathrm{Al}$ were assigned to the $\mathrm{Y}$ site. Also, the absence of a strong factor loading for $\mathrm{Ti}$ in the Al-Fe factor (Table 5, Factor 1) suggests that $\mathrm{Ti}$ is insensitive to variations in $\mathrm{Fe}$ and $\mathrm{Al}$ content. The dodecahedral site $(\mathrm{X})$ is completely occupied by $\mathrm{Ca}$. Where $\mathrm{Ca}$ was insufficient to fill this site, $\mathrm{Mn}$, and rarely $\mathrm{Mg}$, was assigned to $\mathrm{X}$ site.

\section{Origin of Ti-garnets}

Ti-bearing andradite garnets occur in a wide variety of parageneses (Manning and Harris 1970; Deer et al. 1982; Dingwell and Brearley 1985). The majority of Tirich andradite commonly found in the undersaturated alkaline igneous rocks is in the form of primary garnets (e.g. Huggins et al. 1977a, b; Deer et al. 1982; Meagher 1982). Secondary type occurs typically in skarns, veins and metasomatic rocks characterized by low $\mathrm{TiO}_{2}$ content (Deer et al. 1982; Howie and Woolley 1968; Manning and Harris 1970). Russell et al. (1999), Cioni et al. (1995), Naimo et al. (2003), Smith et al. (2004), and Fulignati et al. (2004) distinguished different Tigarnet types on the basis of color, morphology, zonation style, and major oxides criteria. Magmatic Ti-garnet crystallized in alkaline rocks such as syenite and nepheline syenite are dark brown or black in color (Gomes 1969; Turbeville 1993; Lang et al. 1995). This can be related to the large quantity of titanium (>1 wt $\%$ ) (Scheibner et al. 2007). In contrast, Ti-garnet produced during metasomatic or 
hydrothermal processes are red, yellow, brown and green (because of their low $\mathrm{TiO}_{2}$ contents).

A euhedral shape for garnet is considered as a common feature of primary origin, whereas interstitial or irregular grains reflect complex late stage (metasomatic) crystallization of garnet due to reactions of earlier mafic minerals with late stage fluids.

Armbruster et al. (1998), studying the crystal chemistry of Ti-bearing garnets of different origins, suggest a correlation between petrogenesis and Ti-substitutions in these minerals. Garnet crystals with schorlomite substitution $\left(\mathrm{Ti}^{4+} \rightarrow \mathrm{Si}^{4+}\right)$ are of magmatic origin whereas crystals with combined morimotoite $\left(\mathrm{Fe}^{2+}+\mathrm{Ti}^{4+} \rightarrow 2 \mathrm{Fe}^{3+}\right)$ and hydrogarnet substitutions $\left(\mathrm{O}_{4} \mathrm{H}_{4} \rightarrow \mathrm{SiO}_{4}\right)$ frequently originate in metamorphic rocks. Garnets in skarns exhibit a mixture between morimotite and schorlomite substitutions (Armbruster et al. 1998). Ti-rich garnet in skarns forms after the breakdown of titanian-bearing phases such as titanite and ilmenite under oxidizing conditions and low values of $\mathrm{SiO}_{2}$ in the silicate melt or in the hydrothermal fluid (Russell et al. 1999; Katerinopoulou et al. 2009).

The Ti-rich garnets of the Kaleybar nepheline syenite are proposed to have been generated from the evolved alkaline silica-undersaturated magmas. Some supporting petrographic and chemical evidence for magmatic origin is the fact that Ti-garnet in the investigated rocks occurs as individual euhedral to subhedral grains displaying dark brown color (e.g. Nash and Wilkinson 1970; Nash 1972; Woolley 1973; Gwalani et al. 2000). These show complex zoning in major elements. The $\mathrm{TiO}_{2}$ content of Ti-garnets ranges between 1.5 and 5.0 (wt\%). The estimated formula for Ti-garnet has zero or near-zero amounts of $\mathrm{H} 4 \mathrm{Si}-1$ (e.g. Russell et al. 1999). All the observations support an igneous origin for the studied Ti-garnets.

\section{Acknowledgements}

We would like to thank Dr. Pál Molnár and an anonymous reviewer of the journal for their thoughtful reviews and helpful comments. The generous help and efficient editorial handling of the paper by Dr. Attila Demény is highly appreciated.

\section{References}

Amthauer, G., G.R. Rossman 1998: The hydrous component in andradite garnet. - American Mineralogist, 83, pp. 835-840.

Armbruster, T., J. Birrer, E. Libowitzky, A. Beran 1998: Crystal chemistry of Ti-bearing andradites. European Journal of Mineralogy 10, pp. 907-921.

Azambre, B., M. Girod 1966: Phonolites Agpaïtiques. - Bulletin de la Société Française d'Entomologie, 89, pp. 514-520.

Babakhani, A., J.L. Lescuyer, R. Riou 1980: Explanation of Ahar quadrangle. - Geological Survey of Iran, $123 \mathrm{p}$. 
Bagdasarian, G.P. 1966: Intrusive rocks of the Basumo-Pambaksky region. - Geology of the Armenian SSR. Petrography. Intrusive rocks; Armenian Academy of Sciences Erevan, 3, pp. 256-308.

Basso, R., A.D. Giusta, L. Zefiro 1981: A crystal chemical study of a Ti-containing hydrogarnet. Neues Jahrbuch für Mineralogie Monatshefte, 5, pp. 230-236.

Chakhmouradian, A.R., C.A. McCammon 2005: Schorlomite: a discussion of the crystal chemistry, formula, and inter-species boundaries. - Physics and Chemistry of Minerals, 32, pp. 277-289.

Cioni, R., L. Civetta, P. Marianelli, N. Metric, R. Santacroce, A. Sbrana 1995: Compositional layering and syn-eruptive mixing of a periodically refilled shallow magma chamber, the AD 79 plinian eruption of Vesuvius. - Journal of Petrology, 36, pp. 739-776.

Deer, W.A., R.A. Howie, J. Zussman 1982: Orthosilicates. In Rock-Forming Minerals. - 1A; 2nd ed. Longman, London, UK.

Deer, W.A., R.A. Howie, J. Zussman 1997: Rock-Forming Minerals Volume 1A: Orthosilicates. - 2nd Edition, Geological Society, London.

Dingwell, D.B., M. Brearley 1985: Mineral chemistry of igneous melanite garnets from analcitebearing volcanic rocks, Alberta, Canada. - Contributions to Mineralogy and Petrology, 90, pp. $29-35$.

Droop, G.T.R. 1987: A general equation for estimating $\mathrm{Fe}^{3+}$ concentrations in ferromagnesian silicates and oxides from microprobe analyses using stoichiometric criteria. - Mineralogical Magazine, 51, pp. 431-435.

Fulignati, P., P. Marianelli, R. Santacroce, A. Sbrana 2004: Probing the Vesuvius magma chamberhostrock interface through xenoliths. - Geological Magazine, 141, pp. 417-428.

Green, T.H. 1977: Garnet in silicic liquids and its possible use as a P-T indicator. - Contributions to Mineralogy and Petrology, 65, pp. 59-67.

Gomes, C.B. 1969: Electron microprobe analysis of zoned melanites. - American Mineralogist, 54, pp.1654-1661.

Gukasian, R.X. 1963: Determination of the absolute age by the Rb-Sr method on a sample from the Megrinsky pluton Armenian SSR; Doklady Akademii Nauk Armyanskoi SSR. - Seriya Geologiya, 36/3, pp. 173-178.

Gwalani, L.G., N.M.S. Rock, R. Ramasamy, B.J. Griffin, B.P. Muglia Mitchell 2000: Complexly zoned Ti-rich melanite-schorlomite garnets from Ambadungar carbonatite-alkalic complex, Deccan Igneous Province, Gujarat State, Western India. - Journal of Asian Earth Science, 18, pp. 163-176.

Hajialioghli, R. 2002: Investigation of contact metamorphism of pelitic and calc-silicate rocks in the Kaleybar aureole. Implications for crustal evolution of the studied area. - Unpublished MSc Thesis University of Tabriz, $145 \mathrm{p}$.

Hartman, P. 1969: Can $\mathrm{Ti}^{4+}$ replaces $\mathrm{Si}^{4+}$ in silicates? - Mineralogical Magazine, 37, pp. 366-369.

Hawthorne, F.C. 1981: Crystal chemistry of the amphiboles. - Mineralogical Society of America, Review in Mineralogy, 9(A), pp. 1-102.

Hoffmann, G.C. 1902: Report of the section of chemistry and mineralogy. - Geological Survey of Canada Annual Report, 12, 12R-13R.

Howie, R.A., A. Woolley 1968: The role of titanium and the effect of $\mathrm{TiO}_{2}$ on the cell-size, refractive index and specific gravity in the andradite-melanite-schorlomite series. - Mineralogical Magazine, 36, pp. 775-970.

Huggins, F.E., D. Virgo, H.G. Huckenholz 1977a: Titanium-containing silicate garnets. I. The distribution of $\mathrm{Al}, \mathrm{Fe} 3+$, and Ti4+ between octahedral and tetrahedral sites. - American Mineralogist, 62, pp. 475-490.

Huggins, F.E., D. Virgo, H.G. Huckenholz 1977b: Titanium-containing silicate garnets. II. The crystal chemistry of melanites and schorlomites. - American Mineralogist, 62, pp. 646-665.

Jiang, N., S. Sun, X. Chu, T. Mizuta, D. Ishiyama 2003: Mobilization and enrichment of high-field strength elements during late- and post-magmatic processes in the Shuiquangou syenitic complex, Northern China. - Chemical Geology, 200, pp. 117-128. 
Kazempour, E. 2004: Mineralogy, alteration, geochemistry, and probable genesis of $\mathrm{Cu}$ mineralization from Alijavad, Ahar area. - Unpublished MSc thesis, University of Tabriz, $116 \mathrm{p}$.

Katerinopoulou, A., A. Katerinopoulos, P. Voudouris, A. Bieniok, M. Musso, G. Amthauer 2009: A multi-analytical study of the crystal structure of unusual Ti-Zr-Cr-rich andradite from the Maronia skarn, Rhodope massif, western Thrace, Greece. - Mineralogy and Petrology, 95/1-2, pp. 113-124.

Koenig, G.A. 1886: On schorlomite as a variety of melanite. - Proceedings of the Academy of Natural Sciences of Philadelphia, pp. 355-357.

Kogarko, L.N., V. A. Kononova, M.P. Orlova, A.R. Wooley 1995: Alkaline Rocks and Carbonatites of the World. - Chapman and Hall, $230 \mathrm{p}$.

Kretz, R. 1983: Symbols for rock-forming minerals. - American Mineralogist, 68, pp. 277-279.

Kunitz, W. 1936: Die Rolle des Titans und Zirkoniums in den gesteinsbildenden Silikaten. - Neues Jahrbuch für Mineralogie, 70 (A), pp. 385-466.

Lang, J.R., B. Lueck, J.K.Mortensen, J.K. Russell, C.R. Stanley, J.F.H. Thompson 1995: Triassic-Jurassic silica-undersaturated and silica-saturated intrusions in the Cordillera of British Columbia: implications for arc magmatism. - Geology, 23, pp. 451-454.

Larsen, E.S. 1942: Alkaline rocks of Iron Hill, Gunnison County, Colorado, US. - Geological Survey Professional Paper, 197-A.

Locock, A., R.W. Luth, R.G. Cavell, D.G.W. Smith, M.J.M. Duke, 1995: Spectroscopy of the cation distribution in the schorlomite species of garnet. - American Mineralogist, 80, pp. 27-38.

Manning, P.G., D.C. Harris 1970. Optical absorption and electron-microprobe studies of some highTi Andradites. - Canadian Mineralogist, 10, pp. 260-271.

McCammon, C. 2005: Mantle oxidation state and oxygen fugacity: Constraints on mantle chemistry structure and dynamics. - In: Hilst, R.D.v.d., J. Bass, J. Matas, J. Trampert (Eds): Earth's Deep Mantle: Structure, Composition, and Evolution. - American Geophysical Union, Washington D.C., pp. 221-242.

Meagher, E.P. 1982: Silicate garnets. In Ribbe, P. H., ed., Orthosilicates. - Review in Mineralogy, 5, pp. $25-66$.

Mitchell, R.H., R.G. Platt 1979: Nepheline-bearing rocks from the Poohbah Lake alkaline complex, Ontario; Malignites and malignites. - Contributions to Mineralogy and Petrology, 69, pp. $255-264$.

Morimoto, N., J. Fabries, A.K. Ferguson, I.V. Ginzburg, M. Ross, F.A. Seifert, J. Zussman, K. Aoki, G. Gottardi 1989: Nomenclature of pyroxenes. Subcommittee on Pyroxenes. - American Mineralogist, 73, pp. 1123-1133.

Morimoto, N. 1989: Nomenclature of pyroxenes. - Canadian Mineralogist, 27, pp. 143-156.

Nabavi, M.H. 1976: An Introduction to the Geology of Iran. - Geological Survey of Iran, 109. (In Persian.)

Naimo, D., G. Balassone, A. Beran, C. Amalfitano, M. Imperato, D. Stanzione 2003: Garnets in volcanicbreccias of the Phlegraean Fields (southern Italy): mineralogical, geochemical and genetic features. - Mineralogy and Petrology, 77, pp. 259-270.

Nash, W.P. 1972: Mineralogy and petrology of the Iron Hill carbonatite complex, Colorado. Geological Society of America Bulletin, 83, pp. 1361-1382.

Nash, W.P., J.F.G. Wilkinson 1970: Shonkin Sag Laccolith, Montana. I. Mafic minerals and estimates of temperature, pressure, oxygen fugacity and silica activity. - Contribution to Mineralogy and Petrology, 25, pp. 241-269.

Novak, G.A., G.V. Gibbs 1971: The crystal chemistry of silicate garnets. - American Mineralogist, 56, pp. 791-825.

Onuki, H., T. Yoshida, M. Nedachi 1981: Electron probe study of Ti-rich hydroandradites in the Sanbagawa metamorphic rocks. - Japan Association of Mineralogists, Petrologists and Economic Geologists, 76, pp. 239-247.

Peterson, R. C., A.J. Locock, R.W. Luth 1995: Positional disorder of oxygen in garnet: The crystal structure refinement of schorlomite. - Canadian Mineralogist, 33, pp. 627-631 
Ramasamy, R. 1986: Titanium-bearing garnets from alkaline rocks of carbonatite complex of Tiruppattur, Tamil Nadu. - Current Science, 55, pp. 1026-1029.

Riou, R. 1979: Petrography and geochemistry of the Eocene alkaline lavas of the northern Azerbaijan (Iran). - Neues Jahrbuch fiir Geologie und Paläontologie, Monatshefte, 9, pp. 532-559.

Russell, J.K., G.M. Dipple, J.R. Lang, B. Lueck 1999: Major-element discrimination of titanium andradite from magmatic and hydrothermal environments; an example from the Canadian Cordillera. - European Journal of Mineralogy, 11/6, pp. 919-935.

Sawaki, T. 1988: Melanite and fassaite from the contact aureole around the Nogo-Hakusan granodiorite body, central Japan. - Japan Association of Mineralogists, Petrologists and Economic Geologists, 83, pp. 357-373.

Scheibner, B., G. Wörner, L. Civetta, H.G. Stosch, K. Simon, A. Kronz 2007: Rare earth element fractionation in magmatic Ca-rich garnets. - Contributions to Mineralogy and Petrology, 154, pp. 55-74.

Segalstad, TV. 1979: Petrology of the Skien basaltic rocks, southwestern Oslo Region, Norway. Lithos, 12, pp. 221-239.

Smith, M.P., P. Henderson, T.E.R. Jeffries, J. Long, C. Williams 2004: The rare earth elements and uranium in garnets from the Beinn and Dubhaich Aureole, Skye, Scotland, UK; constraints on processes in a dynamic hydrothermal system. - Journal of Petrology, 45/3, pp. 457-484.

Tarte, P. 1960a: Recherches sur le spectre infrarouge des silicates: II. Determination du role structural du titane dans certains silicates. - Silicates Industrials Brussels, 25, pp. 171-175.

Tarte, P. 1960b: Infrared spectra of garnets. - Nature, pp. 186, 234.

Thompson, Jr., J.B. 1982: Composition space: An algebraic and geometric approach. - In Mineralogical Society of America Reviews in Mineralogy, 10, pp. 1-31.

Turbeville, B.N. 1993: Petrology and petrogenesis of the Latera Caldera central Italy. - Journal of Petrology, 34, pp. 77-124.

Varet, J. 1969: Les pyroxènes des phonolites du Cantal (Auvergne, France). - Neues Jahrbuch für Mineralogie, Geologie und Paläontologie, pp. 174-184.

Woolley, A.R. 1973: The pseudo-leucite Borolanites and associated rocks of the south-eastern tract of the Borralan complex, Scotland. - Bulletin of the British Museum (Natural History) Mineral., 2, pp. 285-333. 